\title{
Respiratory Symptoms Associated with Workplaces Located along a Road with High-Traffic at Cotonou, Benin
}

\author{
Parfait Houngbégnon 1,2,3*, Hervé Lawin², Marius Kêdoté1,2, Affoussatou Amadou4, \\ Eloïc Atindegla ${ }^{3}$, Benjamin Fayomi², Simplice Dossou-Gbétés, Victoire Agueh ${ }^{1}$ \\ ${ }^{1}$ Institut Régional de Santé Publique, University of Abomey-Calavi, Ouidah, Benin \\ ${ }^{2}$ EcoHealth Chair, Faculty of Health Sciences, University of Abomey-Calavi, Cotonou, Benin \\ ${ }^{3}$ Institut de Recherche Clinique du Bénin, Abomey-Calavi, Benin \\ ${ }^{4}$ Unité de Recherche en Microbiologie Appliquée et Pharmacologie des substances naturelles, University of Abomey-Calavi, \\ Abomey-Calavi, Benin \\ ${ }^{5}$ Laboratoire de Mathématiques et leurs Applications de Pau (LMAP) UMR CNRS, Université de Pau et des pays de l'Adour, Pau, \\ France \\ Email: ^parfaith2016@gmail.com
}

How to cite this paper: Houngbégnon, P., Lawin, H., Kêdoté, M., Amadou, A., Atindegla, E., Fayomi, B., Dossou-Gbété, S. and Agueh, V. (2020) Respiratory Symptoms Associated with Workplaces Located along a Road with High-Traffic at Cotonou, Benin. Open Journal of Respiratory Diseases, 10, $32-42$.

https://doi.org/10.4236/ojrd.2020.102004

Received: November 9, 2019

Accepted: April 10, 2020

Published: April 13, 2020

Copyright (C) 2020 by author(s) and Scientific Research Publishing Inc. This work is licensed under the Creative Commons Attribution International License (CC BY 4.0).

http://creativecommons.org/licenses/by/4.0/ (c) (i) Open Access

\begin{abstract}
Objective: Air pollution is becoming one of the public concerns requiring urgent feasible response per local context. Defining accurately the level of exposure of outdoor air pollution effect on health of venders working along main roads and roundabouts with high traffic is important. This study was conducted to assess respiratory health risks on venders associated with different geographical positions in Cotonou. Methods: A cross-sectional study was conducted along the main road with high traffic including three roundabouts in Cotonou. The 194 study participants from all shops, one respondent per shop, were given a unique GPS data associated to indicate the shop's geographical position. The study employed validated questionnaire on respiratory symptoms. Results: Study participants had mean age of 36.26 $( \pm 11.65)$ years with sex ratio of $(\mathrm{M} / \mathrm{F}) 1.8$. Majority $(72.7 \%)$ of study participates reported to have at least one respiratory symptom and $69 \%$ of them were working in non-ventilated rooms. The proportion of having at least one respiratory symptom was significantly different $(\mathrm{p}<0.001)$ between the subpopulations at roundabouts $(96.15 \%)$ and apart from the roundabouts $(64.08 \%)$. The most reported symptoms were cough (47.94\%) and itchy nose (42.27\%). The risk of cough $(\mathrm{OR}=5.15 ; 95 \% \mathrm{CI}=[2.21-12.04] ; \mathrm{p}<0.001)$ and itchy nose symptoms $(\mathrm{OR}=3.44 ; 95 \% \mathrm{CI}=[1.55-7.63] ; \mathrm{p}=0.002)$ were higher in individuals working at the roundabouts compared to those working along the main road. Conclusion: Working in roundabout is associated with more res-
\end{abstract}


piratory symptoms than working in shops along main road. Air pollution mitigation efforts should focus in such settings, taking into account the sub-population of workers in resource limited countries.

\section{Keywords}

Air Pollution, High Traffic, Roundabouts, Vendors, Health Risk, Symptom

\section{Introduction}

Air pollution related to road traffic is a real challenge not only for health, but also for sustainable development and the reduction of environmental inequalities for most major urban areas [1]. Living or working along a main road with high traffic is harmful for the health. Several studies have shown that living near a heavily trafficked road has significant risks to respiratory health [2] [3] [4] [5] [6].

Industrialization and socio-economic situation in urban areas, local air pollution level is increasing and is leading to an increasing rate of mortality and morbidity [7] [8] [9]. Several pollutants emitted into the atmosphere such as fine particulates (PM 2.5) are associated with respiratory diseases such as asthma, flu, etc. [9] [10] [11]. The area of influence of these emissions, however, remains difficult to delimit. Knowledge of pollutant dispersal mechanisms at the street and neighborhood level is still incomplete [8] [12]. Although air pollution is threat globally, it may differently affect people due to activities influencing locally their level of exposure. Working in a room along a main road or in a roundabout with high traffic may lead to a different level of exposure in the workplace [13]. The specificity of this geographical position is rarely taken into account in studies which mainly focused on comparison of health risk in people living or working along main roads and those living or working further away from main roads. The current study took into account this specificity when characterizing respiratory health risks in populations working near the road traffic. Thus, the aim of our study was to see near a road with high traffic if there is a difference in the risk of respiratory symptoms between the subpopulation working at the roundabouts and the subpopulation working outside the roundabouts.

\section{Materials and Methods}

\subsection{Study Site and Population}

This study took place at Cotonou, main economic city of Benin. We have included all the shops that were located on the portion of road in Figure 1 from point $\mathrm{A}$ to point $\mathrm{C}$ via point $\mathrm{B}$. This portion of the road is $4.5 \mathrm{Km}$ long and the traffic is very high throughout the day because it serves the largest market in the city and the port of Cotonou. This road included three roundabouts represented by points $\mathrm{A}, \mathrm{B}$ and $\mathrm{C}$. For example, the main roundabout B is represented on Figure 2. One person per shop was included in the current study. When there 


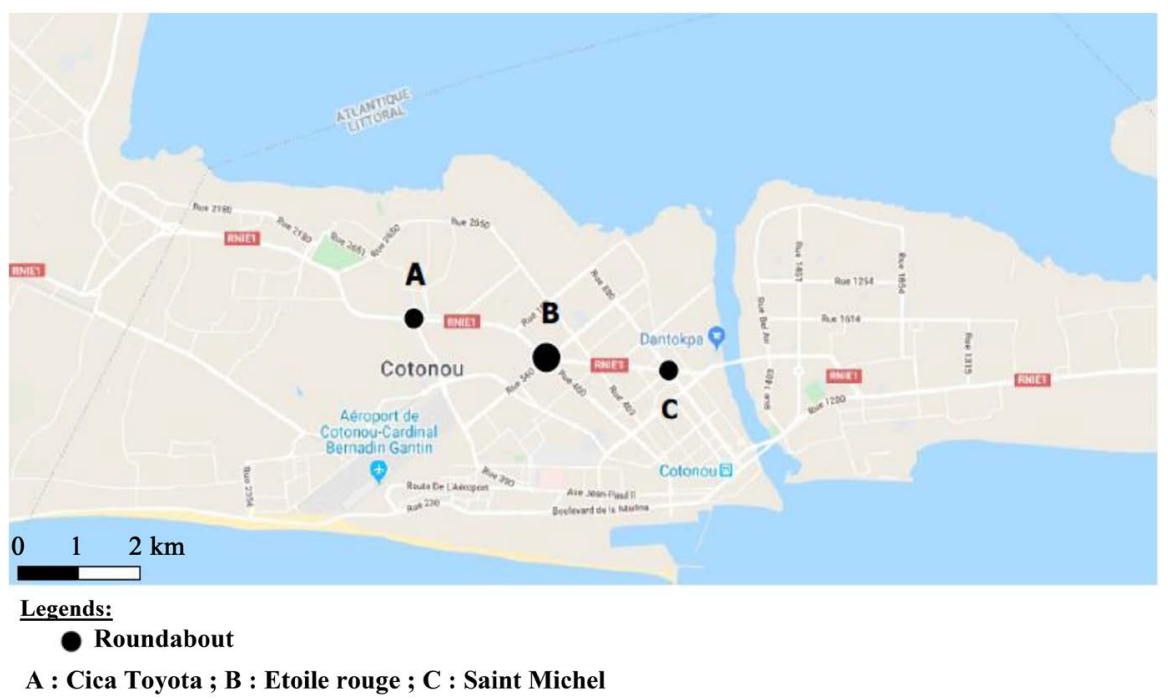

Figure 1. Portion of road concerned by the study.

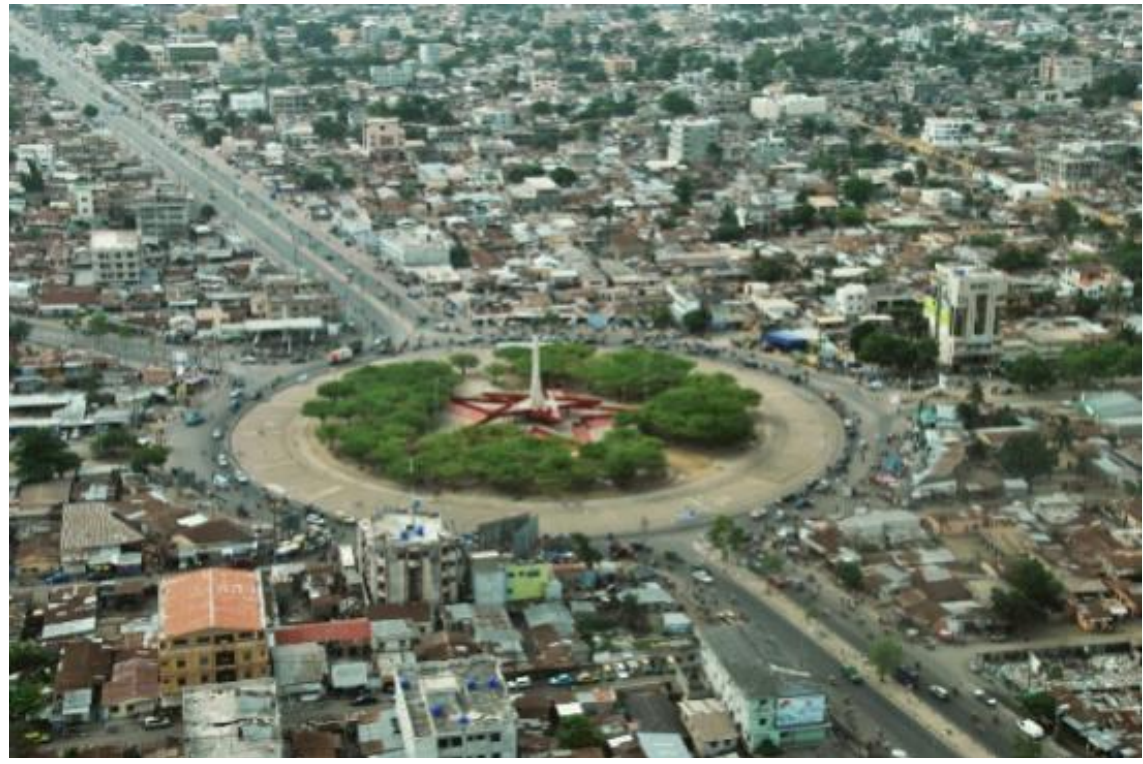

Figure 2. The main roundabout.

was more than one person in the office, we interviewed the oldest one. It allowed us to associate at each respondent a unique GPS coordinates of his workplace. We counted a total of 203 shops in the study site. In 194 of these shops, people accepted to participate in the study so we interviewed 194 individuals.

\section{Data collection}

A validated questionnaire https://www.ncbi.nlm.nih.gov/pubmed/30065166 on respiratory symptoms (cough, expectoration, wheezing, breathlessness, itchy nose) was administered to the participants of the study. The questionnaire also collected information on the ventilation of buildings, the duration of occupation, GPS coordinates and some socio demographic characteristics of the respondents. For data collection we developed an electronic case report form that integrate taking GPS coordinates. The data were collected in November 2018. 


\subsection{Data Analysis}

In the first part, we presented the socio demographic characteristics of the respondents and the frequency of respiratory symptoms. The test of chi-square or t-student was used to compare respectively proportion and mean in the two groups that are roundabout and outside the roundabout. The second part was devoted to the cartography of the different respiratory symptoms.

A logistic regression model was performed to assess the association between the occurrence of respiratory symptoms and the geographical location of participant's workplace (roundabout vs outside of roundabout). For the first model, the dependent variable was cough (presence or absence of symptom). For the second model, the dependent variable was itchy nose (presence or absence of symptom). The both models were adjusted on age, level of instruction, seniority on the site, and aeration of the occupied room. Analysis was performed using Stata software and $\mathrm{p}$-value was considered significant when $\mathrm{p}$-value $<0.05$.

\subsection{Ethical Clearance}

The present study is part of the project ChairePOL that received the final approval ethic on the number $N^{\circ} 032 / M S / D C / S G M / D F R / C N E R S / S A$ du 15 octobre 2018. Based on this, the participants were interviewed after giving their informed consent.

\section{Results}

\subsection{Characteristics of Respondents}

The characteristics of respondents are presented in Table 1 . The sex ratio (M/F) was 1.8. It was 1.6 at roundabout against 1.8 outside the roundabout. The average age of respondents was $36.26 \pm 11.65$ years. There was no statistically significant difference between the two zones $(\mathrm{p}=0.38)$. The study population was predominantly educated (86.6\%). This situation was very different between the two groups. At roundabout, $36.54 \%$ of respondents had not attended school compared to only $4.93 \%$ among respondents outside the roundabout. About $20 \%$ and $60 \%$ of participants have spent respectively at least ten years and at least four years in their job. The distribution of seniority at the place was significantly different between the two zones $(\mathrm{p}<0.001)$. At roundabout nearly half of the respondents had already more than 10 years of seniority at the place compared to only about $10 \%$ of those interviewed along the road. $69.07 \%$ of participants worked in the building that was not well ventilated.

\subsection{Prevalence of Respiratory Symptoms in Relation to Zones}

The proportion of each type of respiratory symptom is presented in Table 2 . $72.68 \%$ of respondents reported having at least one of the five respiratory symptoms. This proportion was significantly different $(\mathrm{p}<0.001)$ between the subpopulation at roundabout (96.15\%) and out the roundabout (64.08\%). The most reported symptoms by the respondents were respectively cough $(47.94 \%)$, 
Table 1. The characteristics of respondents.

\begin{tabular}{|c|c|c|c|c|}
\hline Characteristics & Roundabouts & $\begin{array}{c}\text { Outside } \\
\text { roundabouts }\end{array}$ & Total & p-value \\
\hline Sex & & & & 0.68 \\
\hline Male & $32(61.54 \%)$ & $92(64.79 \%)$ & $124(63.92 \%)$ & \\
\hline Female & $20(38.46 \%)$ & $50(35.21 \%)$ & $70(36.08 \%)$ & \\
\hline Age in classes of years & & & & 0.38 \\
\hline $\begin{array}{l}\text { Mean } \pm \text { Standard } \\
\text { Deviation }\end{array}$ & $37.48 \pm 12.68$ & $35.81 \pm 11.26$ & $36.26 \pm 11.65$ & \\
\hline Educational level & & & & $<0.001$ \\
\hline Not at school & $19(36.54 \%)$ & $7(4.93 \%)$ & $26(13.40 \%)$ & \\
\hline Primary & $13(25.00 \%)$ & $28(19.72 \%)$ & $41(21.13 \%)$ & \\
\hline Lower secondary & $14(26.92 \%)$ & $56(39.44 \%)$ & $70(36.08 \%)$ & \\
\hline High secondary or more & $6(11.54 \%)$ & $51(35.92 \%)$ & $57(29.38 \%)$ & \\
\hline Seniority at the place (years) & & & & $<0.001$ \\
\hline$<1$ & $3(5.77 \%)$ & $15(10.56 \%)$ & $18(9.28 \%)$ & \\
\hline $1-3$ & $7(13.46 \%)$ & $53(37.32 \%)$ & $60(30.93 \%)$ & \\
\hline $4-6$ & $12(23.08 \%)$ & $47(33.10 \%)$ & $59(30.41 \%)$ & \\
\hline $7-9$ & $6(11.54 \%)$ & $13(9.15 \%)$ & $19(9.79 \%)$ & \\
\hline$\geq 10$ & $24(46.15 \%)$ & $14(9.86 \%)$ & $38(19.59 \%)$ & \\
\hline Works and lives in the place & & & & 1 \\
\hline Yes & $4(7.69 \%)$ & $13(9.15 \%)$ & $17(8.76 \%)$ & \\
\hline No & $48(92.31 \%)$ & $129(90.85 \%)$ & $177(91.24 \%)$ & \\
\hline Ventilated room & & & & 0.47 \\
\hline Yes & $14(26.92 \%)$ & $46(32.39 \%)$ & $60(30.93 \%)$ & \\
\hline No & 38 (73.08\%) & 96 (67.61\%) & $134(69.07 \%)$ & \\
\hline
\end{tabular}

Table 2. Proportion of respiratory symptoms according to the zone.

\begin{tabular}{|c|c|c|c|c|}
\hline Respiratory symptoms & $\begin{array}{c}\text { Roundabouts } \\
\text { n (\%) }\end{array}$ & $\begin{array}{c}\text { Outside } \\
\text { roundabouts } \\
\mathrm{n}(\%)\end{array}$ & $\begin{array}{l}\text { Total } \\
\text { n (\%) }\end{array}$ & p-value \\
\hline Cough & & & & $<0.0001$ \\
\hline Yes & $41(78.85)$ & $52(36.62)$ & $93(47.94)$ & \\
\hline No & $11(21.15)$ & $90(63.38)$ & $101(52.06)$ & \\
\hline Spits from the chest & & & & $<0.01$ \\
\hline Yes & $19(36.54)$ & $22(15.49)$ & $41(21.13)$ & \\
\hline No & $33(63.46)$ & $120(84.51)$ & $153(78.87)$ & \\
\hline Whistles & & & & 0.017 \\
\hline Yes & $12(23.08)$ & $14(9.86)$ & $26(13.40)$ & \\
\hline No & $40(76.92)$ & $128(90.14)$ & $168(86.60)$ & \\
\hline
\end{tabular}




\begin{tabular}{|c|c|c|c|c|}
\hline Continued & & & & \\
\hline Breathlessness & & & & 0.003 \\
\hline Yes & $23(44.23)$ & $32(22.54)$ & $55(28.35)$ & \\
\hline No & $29(55.77)$ & $110(77.46)$ & $139(71.65)$ & \\
\hline Itchy nose & & & & $<0.001$ \\
\hline Yes & $36(69.23)$ & $46(32.39)$ & $82(42.27)$ & \\
\hline No & $16(30.77)$ & $96(67.61)$ & $112(57.73)$ & \\
\hline At least one reported symptom & & & & $<0.001$ \\
\hline Yes & $50(96.15)$ & $91(64.08)$ & $141(72.68)$ & \\
\hline No & $2(3.8)$ & $51(35.92)$ & $53(27.32)$ & \\
\hline
\end{tabular}

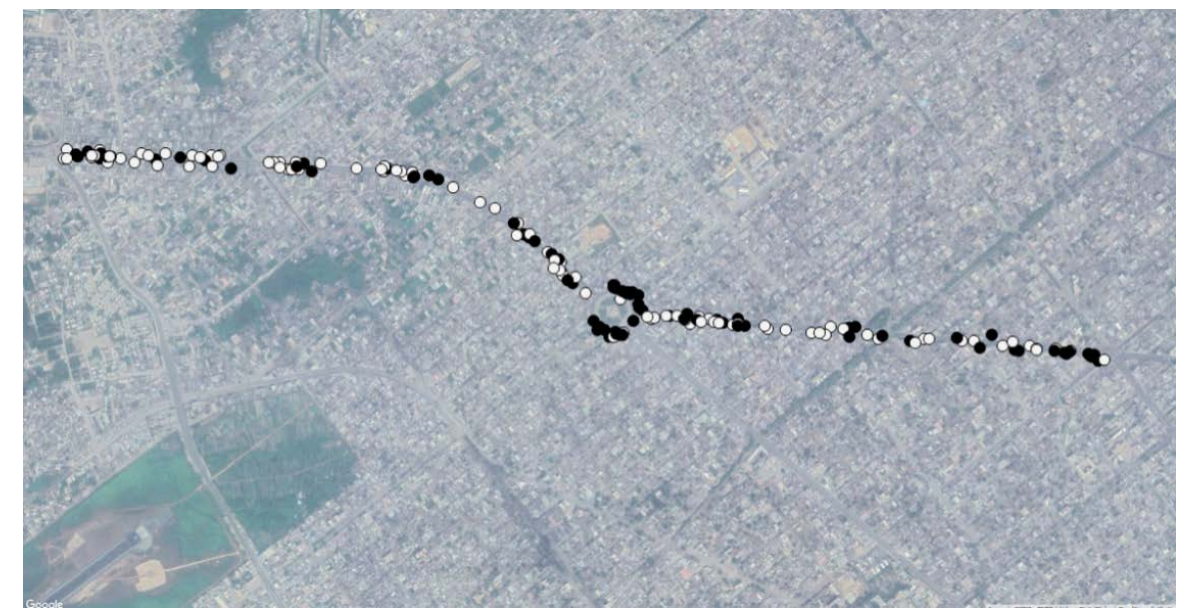

Figure 3. Spatial distribution of cases of presence (black point) and absence (white point) of cough.

itchy nose (42.27\%) and breathlessness (28.35\%). For each of the respiratory symptoms, the proportion was significantly higher at the roundabout than outside the roundabouts.

Figure 3 shows the spatial distribution of symptom of cough.

The multivariate logistic regression to estimate the risk of having a respiratory symptom at roundabout compared to outside the roundabout is presented in Table 3.

The results of logistic regression model showed that the presence of cough and itchy nose were high significantly associated with the place. The risk of cough symptoms was 5.15 higher in a person exercising at the roundabout compared to a person exercising along the $\operatorname{road}(\mathrm{OR}=5.15 ; 95 \% \mathrm{CI}=[2.21 ; 12.04] ; \mathrm{p}$ $<0.001)$. The risk of itchy nose symptoms was 3.44 higher in a person exercising at the roundabout compared to a person exercising along the road $(\mathrm{OR}=3.44$; $95 \% \mathrm{CI}=[1.55 ; 7.63] ; \mathrm{p}=0.002)$.

\section{Discussion}

The aim of this study was to compare the risk of respiratory symptoms between 
Table 3. Multivariate logistic regression to estimate the risk of having a cough or an Itchy nose at roundabout compared to outside the roundabout.

\begin{tabular}{|c|c|c|c|c|c|c|}
\hline & \multicolumn{3}{|c|}{ Cough } & \multicolumn{3}{|c|}{ Itchy nose } \\
\hline & OR & $95 \% \mathrm{CI}$ & $\mathrm{p}$-value & OR & $95 \% \mathrm{CI}$ & p-value \\
\hline \multicolumn{7}{|l|}{ Place } \\
\hline Outside roundabout & 1 & & & 1 & & \\
\hline Roundabout & 5.15 & {$[2.21 ; 12.04]$} & $<0.001$ & 3.44 & {$[1.55 ; 7.63]$} & 0.002 \\
\hline \multicolumn{7}{|l|}{ Age in years } \\
\hline$<25$ & 1 & & & 1 & & \\
\hline $25-34$ & 0.63 & {$[0.22 ; 1.77]$} & 0.38 & 1.51 & {$[0.54 ; 4.2]$} & 0.428 \\
\hline $35-44$ & 0.43 & {$[0.15 ; 1.25]$} & 0.122 & 0.74 & {$[0.26 ; 2.11]$} & 0.569 \\
\hline$\geq 45$ & 0.96 & {$[0.3 ; 3.04]$} & 0.943 & 1.28 & {$[0.41 ; 4.04]$} & 0.67 \\
\hline
\end{tabular}

Educational level

\begin{tabular}{lcccccc} 
Not at school & 1 & & \multicolumn{5}{c}{1} \\
Primary & 0.6 & {$[0.17 ; 2.08]$} & 0.424 & 0.73 & {$[0.22 ; 2.39]$} & 0.607 \\
Secondary or more & 0.48 & {$[0.15 ; 1.5]$} & 0.204 & 0.59 & {$[0.2 ; 1.76]$} & 0.34
\end{tabular}

Seniority at the place

$\begin{array}{lcccccc}\leq 3 & 1 & & & & \\ 4-9 & 1.89 & {[0.59 ; 6.07]} & 0.283 & 0.88 & {[0.29 ; 2.66]} & 0.826 \\ \geq 10 & 1.66 & {[0.45 ; 6.1]} & 0.445 & 1.31 & {[0.38 ; 4.54]} & 0.67\end{array}$

Sex

$\begin{array}{lcccccc}\text { Male } & 1 & & & & & \\ \text { Female } & 1.39 & {[0.71 ; 2.72]} & 0.343 & 1.56 & {[0.79 ; 3.06]} & 0.198\end{array}$

Ventilated room

Yes 1

$\begin{array}{lllllll}\text { No } & 1.1 & {[0.56 ; 2.19]} & 0.779 & 1.5 & {[0.75 ; 3.02]} & 0.251\end{array}$

$\mathrm{OR}=$ Odds Ratio from Multivariate Logistic Regression; $\mathrm{CI}=$ Confidence interval.

the subpopulation working at the roundabouts and the subpopulation working outside of the roundabouts. The analysis of data collected allowed us to highlight some factors that increase the risk of having respiratory symptoms, the prevalence of respiratory symptoms in the proximity of road traffic and finally we have proven that there is a difference in the risk of respiratory symptoms between roundabouts and outside roundabouts.

\subsection{Factors That Increase the Risk of Having Respiratory Symptoms}

The seniority of the participants on their work is very important. Approximately $20 \%$ of them have already spent at least ten years and approximately $60 \%$ have already spent at least four years. The duration of exposure to air pollution, especially road traffic, is an important risk factor in the occurrence of respiratory 
diseases. Indeed, several epidemiological studies have demonstrated that long-term exposure to road traffic as indicated by residential proximity to major roadways or residential traffic intensity is associated with adverse cardiovascular outcomes [14] and cardiopulmonary mortality [15]. Hoek et al. have conducted a pilot cohort study in the Netherlands and found that there was evidence of increasing that long-term exposure to ambient air pollution is associated with deaths from cardiopulmory diseases [16]. In the same vein, Stevanović et al. found that a long term exposure to air pollutants unfavorably influences the health of population and is a risk factor for development and aggravation of certains symptoms and diseases [17]. The analysis of the results of this study also revealed that the majority of the participants worked in non-ventilated rooms. This lack of ventilation leads to a lack of air exchange in the rooms. The compilation of pollutants in the rooms has an accumulating effect, resulting in a condensation of polluted air in them. Thus, in a study conducted in Helsinki and Amsterdam [1], it was estimated that $70 \%$ to $84 \%$ of some pollutants, measured indoors, came from outside (the internal source linked to smoking being absent in this study). The poor ventilation of work rooms close to road traffic is an important risk factor in the occurrence of respiratory diseases.

\subsection{Prevalence of Respiratory Symptoms in the Proximity of Road Traffic}

Our results show that the majority of participants $(72.68 \%)$ reported the presence of at least one respiratory symptom. The cough, the itchy nose, the breathlessness and the spits from the chest were the main respiratory symptoms reported by participants. These results are consistent with the results of Garshick et al. who have found that exposure to vehicular emissions by living near busy roadways might contributed to symptoms of chronic respiratory disease in adults [18]. The similar result was found by Bayer-Oglesby et al. who concluded that living close to main streets or in a dense street network increases the risks for certain respiratory symptoms in adults [19]. In Beijing, long-term exposure to traffic-related air pollution in people who live near major roads was associated with a higher prevalence of chronic cough [20]. And finally, Hegseth et al found statistically significant associations between self-reported TRAP (traffic-related air pollution) exposure and respiratory symptoms in a large, random sample from a population living in an area with modest TRAP levels [21].

\subsection{Difference in Risk of Respiratory Symptoms between Roun- dabouts and Outside Roundabouts}

For the multivariate logistic regression analysis, age, education level, seniority at the place, gender and room ventilation were used as factors to fit the model. The main result highlighted in this work is the difference in risk of respiratory symptoms between roundabouts and outside roundabouts. The risk of cough and itchy nose symptoms were higher in individuals working at the roundabouts compared to those working part from the roundabouts. Zmirou et al., in 2004, 
showed through their study that the risk of developing asthma and respiratory symptoms such as exacerbation of asthma and infections is higher, depending on the location and the distance occupied from each other to road traffic [22] [23].

As we have shown in previous work [13], concentration levels of pollutants, particularly PM2.5, were higher at roundabouts than outside roundabouts.

During periods of low traffic, pollution levels are equivalent to the general atmosphere of the neighborhood where the axis is located. On the other hand, when the road traffic is important, to this general atmosphere is added the pollution directly induced by the traffic [24]. Along the road traffic, it is observed a dispersion of pollutants which reduces the risk incurred by workers near road traffic. The three roundabouts of our study, were located downtown, most of the companies are in town, there is a strong traffic often observed in this area especially to the hours of return of the service. This result is consistent with the results found by Wu et al in 2005 in Southern of California [25]. The presence of traffic lights at roundabouts is an important factor in the health risk associated with air pollution. In peak areas, pollutants released into the air by motorcycles and vehicles create a fog effect in this area. As for stationed workers, their sales room serves as a receptacle for these pollutants in suspension. Hence a transfer of pollution from the outside to the inside of the premises [26]. These indicate that premises near traffic are likely to be more polluted than those located in an environment less directly influenced by pollution sources, although indoor pollution levels are also conditioned by ventilation and the indoor environment [12].

\section{Conclusions}

In this work we were unable to take into account the participants' history of respiratory symptoms and also their exposure outside their workplace. Despite these limitations, our study showed that the risk of respiratory symptoms was higher in the subpopulation exercising at the roundabout compared to the subpopulation exercising along the road. We could conclude that work near roundabouts is more dangerous for respiratory health. However, these two sub-populations are all greatly exposed to respiratory health risks due to their seniority and the non-ventilation of their work rooms.

In resources, poor limited settings, some geographical positions such as roundabouts can be taken into account in the air pollution effect mitigation. In additions to that, efforts must be made to improve the ventilation of the working rooms.

\section{Acknowledgements}

"Le financement de cette étude a été accordé par le Centre de Recherches pour le Développement International (CRDI) dans le cadre du projet "Chairepol" (projet CRDI 107347) de la Communauté de pratique en écosanté pour l'Afrique 
de l'Ouest et du Centre (CoPES-AOC)/Chaire ECOSANTE".

\section{Conflicts of Interest}

The authors declare no conflicts of interest regarding the publication of this paper.

\section{References}

[1] Roussel, I., Frère, S. and Blanchet, A. (2005) Les pollutions atmosphériques urbaines de proximité à l'heure du Développement Durable. Développement durable et territoires, May.

[2] Brauer, M., et al. (2003) Estimating Long-Term Average Particulate Air Pollution Concentrations: Application of Traffic Indicators and Geographic Information Systems. Epidemiology, 14, 228-239.

https://doi.org/10.1097/01.EDE.0000041910.49046.9B

[3] Guéguen, F., Stille, P., Lahd Geagea, M., Perrone, T. and Chabaux, F. (2012) Atmospheric Pollution in an Urban Environment by Tree Bark Biomonitoring-Part II: $\mathrm{Sr}, \mathrm{Nd}$ and $\mathrm{Pb}$ Isotopic Tracing. Chemosphere, 86, 641-647. https://doi.org/10.1016/j.chemosphere.2011.11.008

[4] Honoré, C., Dugay, F. and Pernot, P. (2012) Proximité au trafic routier et pollution de l'air en Ile-de-France. VertigO, 15. https://doi.org/10.4000/vertigo.12805

[5] Karr, C.J., et al. (2009) Infant Exposure to Fine Particulate Matter and Traffic and Risk of Hospitalization for RSV Bronchiolitis in a Region with Lower Ambient Air Pollution. Environmental Research, 109, 321-327. https://doi.org/10.1016/j.envres.2008.11.006

[6] Zhou, Y. and Levy, J.I. (2007) Factors Influencing the Spatial Extent of Mobile Source Air Pollution Impacts: A Meta-Analysis. BMC Public Health, 7, 89-100. https://doi.org/10.1186/1471-2458-7-89

[7] Elichegaray, C., Bouallala, S., Maitre, A. and Ba, M. (2009) État et évolution de la pollution atmosphérique. Revue des Maladies Respiratoires, 26, 191-206. https://doi.org/10.1186/1471-2458-7-89

[8] Franck, M. (2010) Diffusion spatiale de l'urbanisation et de l'industrialisation et formation d'une région urbaine: Le cas de Surabaya, en Indonésie. Annales de Géographie, 671-672, 69. https://doi.org/10.3917/ag.671.0069

[9] Host, S., Chatignoux, E. and Saunal, A. (2012) Impacts sanitaires de la pollution atmosphérique urbaine et des expositions à proximité du trafic routier dans l'agglomération parisienne.

[10] Fourn, L. and Fayomi, E.B. (2006) Air Pollution in Urban Area in Cotonou and Lokossa, Benin. Bulletin de la Société de Pathologie Exotique, 99, 264-268.

[11] Jeannée, N., et al. (2006) Évaluation de l'exposition en zones urbaines à la pollution atmosphérique: Méthodes existantes et application aux PM10 en France métropolitaine. Pollution Atmosphérique.

https://doi.org/10.4267/pollution-atmospherique.1517

[12] Host, S., Chatignoux, E., Leal, C. and Grémy, I. (2012) Exposition à la pollution atmosphérique de proximité liée au trafic: Quelles méthodes pour quels risques sanitaires. Revue dépidémiologie et de Santé Publique, 60, 321-330.

https://doi.org/10.1016/j.respe.2012.02.007

[13] Houngbegnon, P., et al. (2019) Exposure to PM2.5 Related to Road Traffic: Com- 
parison between Crossroads and Outside of Crossroads at Cotonou, Benin. Open Journal of Air Pollution, 8, 108-117. https://doi.org/10.4236/ojap.2019.84006

[14] Hoffmann, B., et al. (2007) Residential Exposure to Traffic Is Associated with Coronary Atherosclerosis. Circulation, 116, 489-496. https://doi.org/10.1161/CIRCULATIONAHA.107.693622

[15] Gehring, U., et al. (2006) Long-Term Exposure to Ambient Air Pollution and Cardiopulmonary Mortality in Women. Epidemiology, 17, 545-551. https://doi.org/10.1097/01.ede.0000224541.38258.87

[16] Hoek, G., Brunekreef, B., Goldbohm, S., Fischer, P. and van den Brandt, P.A. (2002) Association between Mortality and Indicators of Traffic-Related Air Pollution in the Netherlands: A Cohort Study. The Lancet, 360, 1203-1209. https://doi.org/10.1016/S0140-6736(02)11280-3

[17] Stevanović, S. and Nikić, D. (2006) Exposure to Air Pollution and Development of Allergic Rhinitis and Asthma. Medicine and Biology, 1371, 114-118.

[18] Garshick, E., Laden, F., Hart, J.E. and Caron, A. (2003) Residence Near a Major Road and Respiratory Symptoms in U.S. Veterans. Epidemiology, 14, 728-736. https://doi.org/10.1097/01.ede.0000082045.50073.66

[19] Bayer-Oglesby, L., et al. (2006) Living near Main Streets and Respiratory Symptoms in Adults: The Swiss Cohort Study on Air Pollution and Lung Diseases in Adults. American Journal of Epidemiology, 164, 1190-1198. https://doi.org/10.1093/aje/kwj338

[20] Hu, Z.-W., et al. (2016) Living near a Major Road in Beijing: Association with Lower Lung Function, Airway Acidification, and Chronic Cough. Chinese Medical Journal, 129, 2184-2190. https://doi.org/10.4103/0366-6999.189923

[21] Hegseth, M.N., et al. (2019) Self-Reported Traffic-Related Air Pollution and Respiratory Symptoms among Adults in an Area with Modest Levels of Traffic. PLOS ONE, 14.

[22] Zeger, S.L. and Diggle, P.J. (2001) Correction: Exposure Measurement Error in Time-Series Air Pollution Studies. Environmental Health Perspectives, 109, A517. https://doi.org/10.2307/3454839

[23] Zmirou, D., et al. (2004) Traffic Related Air Pollution and Incidence of Childhood Asthma: Results of the Vesta Case-Control Study. Journal of Epidemiology and Community Health, 58, 18. https://doi.org/10.1136/jech.58.1.18

[24] Host, S. (2013) Exposition à la pollution atmosphérique liée au trafic routier et risques sanitaires. VertigO la revue électronique en sciences de l'environnement, No. Hors-série 15. https://doi.org/10.4000/vertigo.12816

[25] Wu, J., Lurmann, F., Winer, A., Lu, R., Turco, R. and Funk, T. (2005) Development of an Individual Exposure Model for Application to the Southern California Children's Health Study. Atmospheric Environment, 39, 259-273. https://doi.org/10.1016/j.atmosenv.2004.09.061

[26] Ogouwale, R. and Houssou, C. (2010) Stratégies de lutte contre la pollution atmosphérique dans la ville de Cotonou (Bénin). 